\title{
Interactive Cities?
}

\section{Local Political Online Communication in Switzerland}

\begin{abstract}
Do city governments and administrations use interactive online tools in their communication? Are they eager to foster interaction with citizens via social networks and microblogs? And what kind of tools do they employ on their websites? We seek to answer these questions with a quantitative analysis of interactive political online communication implemented by city governments and administrations in Switzerland. Results show that more than 70 percent of all Swiss cities $(\mathrm{N}=159)$ offer at least one interactive tool; about one third of the cities are active in social networks. In the French-speaking part of Switzerland more cities use social networks than in the German part, while the Italian-speaking part, Ticino, lags behind.
\end{abstract}

Keywords: local political communication, online communication, social media, Switzerland

\section{Introduction}

A growing number of cities and municipalities are experimenting with online platforms and social media - not only in the spirit of "zeitgeist", but also to better meet the demands of more transparency and citizen participation, reaching out to groups with low political involvement, as teenagers and young adults. Such activities can particularly be observed on the local level, offering the opportunity to focus on local politics that are often not in the centre of political communication research (Lang, 2004).

A large variety of understandings about "interactivity" can be found in the literature (e.g. Kiousis, 2002; Stromer-Galley, 2004; Sundar, Kalyanaraman, \& Brown, 2003). Our approach is based on Kruikemeier et al. (2013), who convincingly argue that the "different understandings have in common that they assume two-way communication" (p. 2), or more generally, interactivity "is the extent to which messages in a sequence relate to each other, and especially the extent to which later messages recount the relatedness of earlier messages" (Rafaeli \& Sudweeks, 1997, no page). With the objective to avoid concepts that are too exclusive and demanding for an assessment of administrations' aspirations to engage with citizens online (such as political participation - involving, at least, the intention of power sharing, Dahlgren 
2013), this study focused on online tools that require and/or invite two-way communication, occurring "when the sending and receiving functions are performed with equal frequency by two or more persons" (Lasswell, 1948, 220). Go \& You (2016) have pointed out that facilitating two-way symmetrical communications between an organization and its public is a defining element of social media and other online platforms. In this sense, interactive online communication means potentially interactive, because facilitating the tools that enable an exchange or dialogue may not be used in this way, or even not at all. Thus, interactive communication implies that two-way communication actually takes place, while interactive media only provide the necessary means for two-way communication. For this study we rely on previous research that have defined and differentiated types of interactive online media (Gibson \& Ward, 2000; Macintosh, 2008; Schweitzer, 2005, 2010; Tambouris, Liotas, \& Tarabanis, 2007; van Veenstra, Janssen, \& Boon, 2011). Previous studies have also underlined the potential inherent in digital media to change (even augment) the relationship between governments, organizations and the public at large, providing new and more opportunities for connecting and dialoguing (e.g. Mossberger, Wu, \& Crawford, 2013; Saffer, Sommerfeldt, \& Taylor, 2013; Thackeray, Neiger, Smith, \& Van Wagenen, 2012).

With Sanders and Canel (2013) we understand the communication of city administrations as government communication, i.e. "the role, practice, aims and achievements of communication as it takes place in and on behalf of public institution(s) whose primary end is executive in the service of a political rationale, and that are constituted on the basis of the people's indirect or direct consent and charged to enact their will" (p. 3). The communication of a city administration in this regard encompasses both the politically motivated communication by an elected government - the political leadership of a city's administration - and the communication by the bureaucratic administrative body which has to refer to its proper public responsibilities (AUTHOR 3, 2005; Baumgartner, 2010). That being said, we will use the terms "government communication" and "administration communication" interchangeably.

Our study connects to analyses on the local level in Western democracies (such as Coleman, 2005; Coleman \& Firmstone, 2014; Geissel, Kolleck, \& Neunecker, 2013; Hilton, 2006). We focus on cities and their efforts to engage their population in online communication, because interactive political online communication can be more often found on the local level with its more salient and tangible issues than on cantonal or national levels (Ladner \& Bühlmann, 2007; Mabileau, Moyser, Parry, \& Quantin, 1989), such as spatial planning, traffic development, gentrification or social cohesion and integration. In this regard, cities can be considered "laboratories" for interactive online communication (Åström \& Grönlund, 2012, p. 76), par- 
ticularly against the background of local direct democracy. Cities and municipalities are experimenting with different forms of consultations and dialogue (e.g. online debates about local public spending in Germanys "Bürgerhaushalten", see Geissel et al., 2013), while federal and cantonal institutions have remained more reluctant (Baumgartner \& Zogg, 2010; Peart \& Ramos Diaz, 2007). One Swiss example is the City of Zurich, which had launched a three-day online deliberation process on five local policy topics in 2011 (AUTHOR1, 2014a). However, until now there were no data available that gave an overview on interactive online communication in Swiss cities, apart from very few single case studies. Studies from other countries (e.g. Borge, Colombo, \& Welp, 2009; Larsson, 2013; Mossberger et al., 2013; Saglie \& Vabo, 2009) suggest that the implementation of interactive media varies with city size, in that larger cities are more apt to adopt and implement. Thus, our present study does not focus on a specific case from one or a few cities, but seeks to provide an assessment to which degree all Swiss cities have implemented interactive features in their online communication.

Against this background, the following research questions are central to our study:

RQ1: Are Swiss cities offering interactive online communication?

RQ2: What kinds of interactive tools have city governments implemented?

RQ3: Is there variation regarding the city size?

\section{Contexts of local government communication in Switzerland}

With regard to political structures, government and administration communication in Switzerland is mainly shaped by three aspects: (1) direct and consociational democracy, (2) subsidiarity and autonomy of cities, and (3) federalism and high diversity of local administrations.

The Swiss political system accustoms citizens to regularly practice political participation in referenda and popular initiatives (e.g. Bützer, 2007; Kriesi \& Trechsel, 2008; Wagschal, 1997). As has been noted in the Sustainable Governance Indicators Index (2015), "Switzerland uses forms of direct democracy to a larger extent than does any other mature democracy. Direct democratic practices are intensively employed on all levels, from the local to the national” (p. 29). Similarly, formal procedures of consociational democracy actively inform stakeholders and invite their participation in decision-making processes (e.g. in formal consultation routines such as "Vernehmlassungen"). On the one hand, these specific features of the 
political structure could either foster interactive online communication or, on the other hand, undermine its inherent potential, because a great many formal and informal participatory mechanisms exist already offline.

Municipal autonomy and subsidiarity result in many political competences on the local level in Switzerland. Swiss cities are competent to implement interactive online communication not only in early stages of the policy cycle (AUTHOR3 et al., 1996), e.g. for problem articulation or problem definition, but also for co-decision making - because Swiss cities actually can decide a large part of their political issues on the local level. Different than in other Western democracies, Swiss cities e.g. hold tax autonomy, own the right to naturalization and autonomously hold local popular referenda.

The various cantonal municipalities' acts (“Gemeindegesetze") lead to a wide array of competences and organizational forms of municipalities: in some municipalities exist parliaments, in others we find recurring citizen assemblies that discuss and decide on local issues (Bützer, 2007; Ladner, 2008). In addition, there exist large differences between the structures of city administrations, resulting from historical developments and influenced by the political system and institutions (Ladner, 2013). As one result, the use of direct democratic institutions at the local level varies with the language region and the size of a municipality (Bützer, 2007).

Concerning media structures, the online communication of governments and administrations in Switzerland are shaped by mainly two aspects: (1) infrastructure and (2) social media savviness. With regard to online media, Switzerland provides a highly developed internet infrastructure, as 86 percent of households have access to high-speed internet (Bundesamt für Statistik [BfS], 2015). The Swiss population is also quite media savvy with over 85 percent Internet users, half of which are active in social media networks (Latzer, Just, Metreveli, \& Saurwein, 2013). In international comparison, this is however a rather low number (Just, Latzer, Metreveli, \& Saurwein, 2013) and below the EU (28) average (BfS, 2015). On the other hand, 71 percent of the Swiss population claim that they seek information from and contact with public administration online (BfS, 2015).

Switzerland consist of three language regions that (aside from the decentralized political system) also lead to regional cleavages concerning culture, attitudes or political behaviour. Even when it comes to both internet penetration and social media use, the language regions vary from each other: internet use is 10 percent lower, internet access of households is 5 percent lower in the Italian speaking part than in the German and French speaking parts (BfS, 2015). At the time of data retrieval for this study (2013), the French speaking part had 10 percent, the 
Italian speaking part 20 percent less mobile internet users than the German speaking part of Switzerland (this gap has become much smaller in the meantime, Latzer et al., 2013; 2015).

RQ4: Is there variation regarding the three language regions of Switzerland?

As a third context factor, the legal situation influences local governments' and administrations' communication. Particularly administrative bodies face strict legal constraints in their communicative behaviour. This may also undermine the inherent interactive potential of online communication.

Administrations are obliged to inform the public on a very broad and general basis (Saxer, 2009; Baumgartner, 2010). On the federal level, the Swiss constitution defined public information as the state's responsibility (art. 180). The Government and Administration Organisation Act (RVOG) of 1997 establishes that the government must communicate and maintain relations with the public. This includes monitoring issues and opinions voiced in public discussions - which can be understood as defining dialogical communication a legitimate tool of government communication (AUTHOR3, 2005).

Although they are obliged to inform the public, governments and administrations must not emit persuasive communication (AUTHOR3, 2005; Baumgartner, 2010; Pasquier, 2013; Saxer, 2009). The topics that administrations may cover in their communication have to remain within their legal spectrum of activity, such as information about their services to the public; information in cases of crisis, official campaigns for the public good (such as health or environment) and information in the context of their formal tasks, such as spatial planning (AUTHOR 3, 2005). As mentioned above, governments - in their function as leading political institutions of a city administration - have more communicational opportunities than the bureaucratic administrative body, but also act and therefore communicate in a corresponding constitutional framework.

In Switzerland, political, media and legal structures vary between cantons and even cities. In this sense, our understanding of "cities" in this study is an ideal type, an abstraction from the multitude of diverging contexts in which their governments and administrations communicate. Moreover, city administrations are heterogeneous organizations with many different units. The focus here is on the communication of the city administration that is directed at the city population, excluding all platforms for tourists, city marketing, attracting investors, and the like. 
In this context, our study seeks to contribute a quantitative account of interactive online communication in Swiss cities that goes beyond appraisal of social network's potential and singlecase studies, but rather provides a comparative view (regarding city size and language region) on its actual implementation in all Swiss cities.

From the above, we expected that the implementation of interactive online media varies among Swiss cities:

H1: Cities with a larger population are more prone to implement interactive online media.

$\mathrm{H} 2$ : Implementation of interactive online media varies among the Swiss language regions.

\section{Material and Method}

Our study includes all the 159 Swiss cities listed in the Statistics of Swiss Cities, published annually by the Union of Swiss Cities (Schweizerischer Städteverband, 2012). Included are all 141 municipalities with a population over 10'000 plus 18 smaller municipalities that have historically attained the status of a city. The sample is representative in terms of distribution of population and across the three Swiss language regions (see Table 1).

\section{TABLE 1: ABOUT HERE}

Our sample includes only interactive media with links from the cities`websites, because only in these cases we could be sure to count official platforms offered by the city administration, not random fake platforms or tourist portals. It may be possible that in some cases communication officials forgot to link to existing social media profiles of the city, or that links were missing for other mistakes. The risk to miss these is however a lesser evil than including false, fake or dead accounts when browsing all sorts of social media platforms for Swiss cities. Also, most social media platforms are not searchable, so that a structural analysis of city websites was the most appropriate method for this RQ.

As the literature on online content or structural analysis suggests (e.g. Brügger, 2010; Luzar, 2004; Rössler \& Wirth, 2001), we archived the websites of all Swiss cities (during the period of Jan 29 - Feb 7, 2013) using Offline Explorer software. A website consists of a multitude of web page layers - each click opens up a new level within the homepage, with another 
URL. For the sampling, we focused on the first-level and second-level web pages (as wellproven in previous studies, e.g. Cho \& Cheon, 2005; Voorveld, Neijens, \& Smit, 2010, 2011). This means that for each city the homepage, defined by the URL of the start page, and all web pages one click around it were considered relevant. In addition, we also included the websites of the political departments of the city administrations, because interactive communication may be linked to certain policy fields rather than be present on the first two levels of city portals. These were also treated as start pages. In total we analysed 500 first-level (start) web pages (159 homepages of cities, 341 start pages of the city departments) with a link-depth of two levels each. First, the start page was searched for interactive tools and coded, from top left to bottom right (as described by McMillan, Hoy, Kim, \& McMahan, 2008). Secondly, the coders clicked all links on the start page (from top left to bottom right) and then coded the connected websites within the city's domain. On all variables inter-coder reliability (Holsti) varied between $0.77-0.87$ (see appendix).

To identify interactive tools for RQ1 and RQ2, we differentiated various types based on previous studies: social networking sites (e.g. Facebook), social sharing buttons, micro blogs (e.g. Twitter), video platforms (e.g. YouTube), discussion forums, blogs and chats (Gibson \& Ward, 2000; Macintosh, 2008; Schweitzer, 2005, 2010; Tambouris et al., 2007; van Veenstra et al., 2011): Because 46 percent of Swiss internet users access online communication from mobile tools (Latzer et al., 2013), we also coded mobile apps offered by the cities. We also included online-surveys because they are intended to generate popular feedback; newsletters and RSS feeds, because they require subscription, and blogs or wikis, because they may be primarily content sharing sites (Go \& You, 2016), but invite user feedback nevertheless. Interactive media (affording reciprocal communication of two or more participants) outside of these categories were coded as "other". Those tools are interactive to variable degrees - in that they afford both sending and receiving functions for two or more persons, providing the opportunity for exchange and interaction between city administrations and the local population. We also coded whether these tools were explicitly connected to a particular stage in the policy-circle, i.e. the stages of the policy-making process: problem articulation, problem definition, program development, implementation, evaluation (AUTHOR3, 1996) and the type of potential participation: informing, consulting, advising, co-production, co-decision (van Veenstra et al. 2011).

\section{Results}




\subsection{Swiss regions and interactive online communication}

The analysis shows that $72 \%$ (114) of all Swiss cities have implemented interactive tools on their websites (see Table 2). No interactive online communication was found on the websites of 45 Swiss cities. In sum, we examined 409 interactive tools, distributed over the websites of 114 cities: $82 \%$ (336) were located on the websites of 86 cities in the German-speaking part of Switzerland, $16.4 \%$ (67) on websites of 26 cities in the French-speaking part and only $1.5 \%$ (6) on the websites of two cites in the Italian-speaking part, Ticino. In other words: While 75 $\%$ (86) of the cities in the German-speaking part had implemented interactive online media, and, almost on par, $72 \%$ (26) in the French-speaking part, only $40 \%$ (2) of the cities in the Italian speaking part had done the same. Thus, $\mathrm{H} 2$ is confirmed, with the limitation that the sample of cities in the Italian-speaking part is comparatively small, because there only are five cities in this language region.

\section{TABLE 2: ABOUT HERE}

\section{TABLE 3: ABOUT HERE}

We found 80 links to official city profiles or groups on social network sites (SNS) on the websites of all Swiss cities (see Table 3). Cities use mainly Facebook, while Google Plus, Flickr and Foursquare play only a marginal role. In 15 cities we retrieved more than one link to SNS. Zurich, Switzerland's largest city, accounted for a total of 18 SNS (all Facebook).

As mentioned above, previous studies found that the more populous a municipality, the higher the online activity of the local administration (Borge et al., 2009; Larsson, 2013; Saglie \& Vabo, 2009). For this reason, we related the city size (a city's resident population) with interactive online media (number of interactive tools found on city websites). Table 4 shows the distribution of interactive tools over different size categories.

\section{TABLE 4: ABOUT HERE}


The six cities with more than 100'000 inhabitants offer nearly 30 percent of all the interactive tools. Comparing this group of cities to the other categories, city size seems to have an effect on the number of interactive tools. At a first glance there is a strong correlation between the two variables "city size" and "number of interactive tools" with $r(P E A R S O N)=0.83$. However, the sample is fairly unbalanced in terms of city size, because only ten cities have a population higher than 50.000. Moreover, Zurich is a special case: The most populous Swiss city with almost twice as many inhabitants as the second largest city Geneva, Zurich also offers disproportionally more interactive tools than other cities. When we exclude Zurich from calculating the correlation of city size and number of interactive tools, the Pearson Coefficient declines to $r=0.57$. There is a strong bias caused by Zurich, where we found nearly 15 percent (59) of all interactive tools. Thus, H1 is only partially confirmed: the effect of city population size is strong between the many small and the very few large cities, but only moderate among the medium sized cities.

A closer look at the 409 interactive tools on all city websites reveals their predominantly generic and informative character. This is also reflected in the categorization of those tools: more than half of them are used for the provision of information, while only very few tools could be found that enable consulting or advising by citizens. The same applies to the mode of interaction, with, again, more than half (215) of the 409 elements functioning as "one-tomany" channels of interaction. With many social networking sites in the picture, about one third of the tools enable many-to-many communication that could potentially be dialogic or even discursive. We could assign only twelve of all the 409 coded interactive tools to a position in the policy-cycle. For all the others (97 percent) we could not determine any clear relation to stages of policy-making processes, because they were generic platforms.

The high number of generic interactive media without a clear connection to stages of the policy cycle, illustrates that the cities may incorporate social networks and other media on their websites, but do not necessarily use them to increase dialogue with citizens. In this regard most online activities are not intentionally orientated to political participation and can rather be seen as permanent feedback channels for citizens to get in touch with different parts of city administrations or governments. The results also clearly show that Swiss cities do not employ interactive online communication on later stages of the policy cycle, particularly in decisionmaking process. In the structural setting of direct democracy this evokes severe doubts about 
the intentions of Swiss cities to engage their population via interactive online communication. Swiss cities offer rather generic channels for online interaction, if at all aimed at defining and aggregating problems, but not for online consultation, co-decision or co-decision-making.

\section{Discussion}

Our results show that Swiss cities have to a large extent implemented interactive online communication, but rather as generic add-on channels. Social media have become a standard communication channel in many cities, but in most cities they are hardly used to foster more citizen dialogue, let alone political participation. An important next step would be to conduct a content analysis of local online communication on interactive media to scrutinize whether interactivity is indeed taking place. Interviews with the cities' heads of communication can provide additional insight into the motivations to implement interactive media for local government communication. We have already presented the perceptions of city administrations about interactive and participatory online communication elsewhere (AUTHORS, 2015).

While this analysis certainly has some serious limitations (download of websites at one point in time; reduction of analysis to two levels of city homepages and departmental homepages), it underscores findings from previous quantitative analyses that went beyond successful single cases and allows for some critical remarks. Although our data is descriptive statistics and we cannot address why the prevalent pattern has emerged, we will sketch out some tentative conclusions that can be drawn with regard to Switzerland's political, media and legal context.

The opportunity structure of political participation and direct democracy in the Swiss political systems, particularly on the local level, limits the demand for online dialogue and involvement. In Switzerland, citizens have a broad range of offline opportunities to voice discontent and participate in legally binding decision-making, as described in section 2. Social media offered by public administration thus do not fulfil the function of a valve, an opportunity for the public to let off some steam. On the contrary, discussions on social media are not legally binding and therefore may be less attractive for public mobilization than offline "old school" direct democratic mechanisms.

At the same time, interactive online media are no functional equivalents to traditional mass media. Social networks, for example, are primarily used for identity management and self- 
presentation (Gustafsson, 2010; van Dijck, 2013). Microblogs, such as Twitter, are used as broadcasting tools with only limited dialogical potential (AUTHOR1, 2013) and, as most social media, for mass self-communication and expression (Fenton, 2012). For public administrations then, interactive online media are not a way to circumvent journalistic gatekeeping or to compensate for coverage in crisis-plagued local news media. Quite on the contrary, interactive online media are extra channels, making public communication more demanding for the cities' communication officers.

From the perspective of citizens as apt users of social media, the implementation of interactive online media may be expected as a contemporary matter of course. But at the same time online media are hardly used for political information and political engagement by citizens (Emmer, Vowe, \& Wolling, 2011). The main reason for that is that entertainment, interpersonal communication and information retrieval remain the main activities online. This may also be connected to trust issues, although the perceived trustworthiness of online information from public administrations is rather high in Switzerland (Just et al., 2013). Overall, the Swiss population is rather reluctant when it comes to political participation online. In a representative survey, 46 percent perceived the internet as an unsafe place for political expression and preferred to talk about politics offline, and only a small minority believed that the quality of democracy would benefit from online communication (Just et al., 2013).

Considering this background, it is less striking that city administrations are hardly offering any opportunities to participate online that go beyond one-way information via newsletters, RSS feeds or social networks. Our findings show that we should not overestimate the transformative or political potential of interactive online media in the context of local political communication. Most certainly, these results should extend our view beyond the potential of online media for political communication and direct research at both the tangible motivations and contexts that drive the implementation of interactive online communication as well as the actual contents of interactive online media provided by cities.

Acknowledgement: This study was funded by the Swiss National Science Foundation.

\section{References}

Åström, J., \& Grönlund, Å. (2012). Online consultations in local government: What works, when, and why. In S. Coleman \& P. Shame (Eds.), Connecting democracy: Online consultation and the flow of political communication (pp. 75-96). Cambridge (Mass.): MIT Press. 
AUTHOR1 (2013)

AUTHOR1 (2014a)

AUTHOR1 (2014b)

AUTHOR3 et al. (1996)

AUTHOR3 (2005)

AUTHOR3 (2008)

AUTHORS (2015)

Baumgartner, S. (2010). Die Regierungskommunikation der Schweizer Kantone. Regeln, Organisation, Akteure und Instrumente im Vergleich. Wiesbaden: VS.

Baumgartner, S., \& Zogg, J. (2010). Das Internet als Instrument politischer Öffentlichkeitsarbeit der Schweizer Kantone. In J. Wolling, M. Seifert, \& M. Emmer (Eds.), Politik 2.0? Die Wirkung computervermittelter Kommunikation auf den politischen Prozess (pp. 43-58). Baden-Baden: Nomos.

BfS-Bundesamt für Statistik (2015). Internetzugang der Haushalte und Internetnutzung der Bevölkerung in der Schweiz. Retrieved from

http://www.bfs.admin.ch/bfs/portal/de/index/news/publikationen.html?publicationID=6594, http://www.bfs.admin.ch/bfs/portal/de/index/themen/16/04/key/approche_globale.indicator.30109.2.html, 13.07.2015.

Borge, R., Colombo, C., \& Welp, Y. (2009). Online and offline participation at the local level: A quantitative analysis of the Catalan municipalities. Information, Communication \& Society, 12(6), 899-928. doi:10.1080/13691180802483054

Brügger, N. (2010). Web archiving. Between past, present, and future. In M. Consalvo, \& C. Ess (Eds.), The Handbook of Internet studies (pp. 24-42). Malden (Mass.): Wiley-Blackwell.

Bützer, M. (2007). Direkte Demokratie in Schweizer Städten. Ursprung, Ausgestaltung und Gebrauch im Vergleich. Baden-Baden: Nomos.

Cho, C.H., \& Cheo, H.J. (2005). Cross cultural comparison of interactivity on corporate websites. Journal of Advertising, 34(2), 99-115. doi:10.1080/00913367.2005.10639195

Coleman, S. (2005). From the ground up. An evaluation of community focused approaches to e-democracy. Retrieved from https://askbristol.files.wordpress.com/2011/10/cx-e-democracy-ground-up.pdf, 17.08.2015

Coleman, S., \& Firmstone, J. (2014). Contested meanings of public engagement: Exploring discourse and practice within a British city council. Media, Culture \& Society, 36(6), 826-844. doi:0163443714536074.

Dahlgren, P. (2013). The political web: Media, participation and alternative democracy. Basingstoke: Palgrave Macmillan.

Emmer, M., Vowe, G., \& Wolling, J. (2011). Bürger Online. Die Entwicklung der politischen OnlineKommunikation in Deutschland. Konstanz: UVK.

Fenton, N. (2012). The internet and social networking. In J. Curran, N. Fenton, \& D. Freedman (Eds.), Misunderstanding the internet (pp. 123-148). London: Routledge.

Geissel, B., Kolleck, A., \& Neunecker, M. (2013). Projektbericht „,Wissenschaftliche Begleitung und Evaluation des Frankfurter Bürgerhaushaltes 2013“. Retrieved from http://www.fb03.unifrankfurt.de/46461594/Buergerhaushalt-Frankfurt---Evaluationsbericht_Final.pdf, 17.08.2015.

Gibson, R. K., \& Ward, S. (2000). A proposed methodology for studying the function and effectiveness of party and candidate web sites. Social Science Computer Review, 18(3), 301-319. doi:10.1177/089443930001800306

Go, E., \& You, K. H. (2016). But not all social media are the same: Analyzing organizations' social media usage patterns. Telematics and Informatics, 33(1), 176-186.

Gustafsson, N. (2010). This time it's personal: Social networks, viral politics and identity management. In D. Riah, \& A. Maj (Eds.), Emerging practices in cyberculture and social networking (pp. 3-24). Amsterdam: Rodopi. 
Hilton, S. (2006). Developing local e-democracy in Bristol. From information to consultation to participation and beyond. Aslib Proceedings: New Information Perspectives, 58(5), $416-428$. doi:10.1108/00012530610692366

Just, N., Latzer, M., Metreveli, S., \& Saurwein, F. (2013). Switzerland on the Internet: An overview of diffusion, usage, concerns and democratic implications. Studies in Communication Sciences, 13(2), 148-155. doi:10.1016/j.scoms.2013.11.002

Kiousis, S. (2002). Interactivity: A concept explication. New Media \& Society, 4(3), $355-383$. doi:10.1177/146144480200400303

Kriesi, H., \& Trechsel, A. H. (2008). The politics of Switzerland: Continuity and change in a consensus democracy. Cambridge: Cambridge University Press.

Kruikemeier, S., van Noort, G., Vliegenthart, R., \& de Vreese, C. H. (2013). Getting closer: The effects of personalized and interactive online political communication. European Journal of Communication, 28(1), 53-66. doi:10.1177/0267323112464837

Künzler, M. (2013). Mediensystem Schweiz. Konstanz: UVK.

Ladner, A. (2008). Die Schweizer Gemeinden im Wandel: Politische Institutionen und lokale Politik. ChavannesLausanne: IDHEAP.

Ladner, A. (2013). Einleitung. In A. Ladner et al. (Eds.), Handbuch der öffentlichen Verwaltung in der Schweiz (pp. 19-22). Zürich: Rüegger.

Ladner, A., \& Bühlmann, M. (2007). Demokratie in den Gemeinden. Der Einfluss der Gemeindegrösse und anderer Faktoren auf die Qualität der lokalen Demokratie. Zürich: Rüegger.

Lang, S. (2004): Local political communication. In F. Esser, \& B. Pfetsch (Eds.), Comparing political communication (pp. 151-183). New York: Cambridge University Press.

Larsson, A. O. (2013). Bringing it all back home? Social media practices by Swedish municipalities. European Journal of Communication, 28(6), 681-695. doi:10.1177/0267323113502277

Lasswell, H. D. (1948). The structure and function of communication in society. In L. Bryson (Ed.), The Communication of Ideas (pp. 215-228). New York: The Institute for Religious and Social Studies.

Latzer, M., Just, N., Metreveli, S., \& Saurwein, F. (2013). Internet-Anwendungen und deren Nutzung in der Schweiz. Themenbericht aus dem World Internet Project - Switzerland 2013. Retrieved from http://www.mediachange.ch/media//pdf/publications/Anwendungen_Nutzung_2013.pdf, 26.08.2014.

Latzer, M., Just, N., Metreveli, S., Saurwein, F. (2013/2015). Internetverbreitung und digitale Bruchlinien in der Schweiz. Themenbericht aus dem World Internet Project - Switzerland 2013/2015. Universität Zürich, Zürich. 26.08.2014, 19.05.2016.

Luzar, K. (2004). Inhaltsanalyse von webbasierten Informationsangeboten. Framework für die inhaltliche und strukturelle Analyse. Norderstedt: Books on Demand.

Mabileau, A., Moyser, G., Parry, G., \& Quantin, P. (1989). Local politics and participation in Britain and France. Cambridge, UK: Cambridge University Press.

Macintosh, A. (2008). E-democracy and E-participation research in Europe. In H. Chen et al. (Eds.), Digital government. E-government research, case studies and implementation (pp. 85-102). Wiesbaden: VS.

McMillan, S., Hoy, M. G., Kim, J., \& McMahan, C. (2008). A multifaceted tool for a complex phenomenon: coding web-based interactivity as technologies for interaction evolve. Journal of Computer-Mediated Communication, 13(4), 794-826.

Meier, W.A., \& Leonarz, M. (2014). Politikberichterstattung in Gemeinden und Bezirken. Eine Übersicht zu Regionalmedien. Bericht für das Bundesamt für Kommunikation BAKOM. Zürich: SwissGis.

Mossberger, K., Wu, Y., \& Crawford, J. (2013). Connecting citizens and local governments? Social media and interactivity in major US cities. Government Information Quarterly, 30(4), 351-358.

Pasquier, M. (2013). Die Kommunikation der Verwaltung und der öffentlichen Organisationen. In A. Ladner et al. (Eds.), Handbuch der öffentlichen Verwaltung in der Schweiz. (pp. 399-421). Zürich: Verlag Neue Zürcher Zeitung.

Peart, M. N., \& Ramos Diaz, J. (2007). Comparative project on local e-democracy initiatives in Europe and North America. Submitted for consideration to the European Science Foundation - Toward Electronic 
Democracy (TED) Program. Retrieved from http://www.edemocracycentre.ch/files/ESF\%20\%20Local\%20E-Democracy.pdf, 18.08.2015.

Rafaeli, S., \& Sudweeks, F. (1997). Networked interactivity. Journal of Computer-Mediated Communication, 2(4), 0-0.

Rössler, P., \& Wirth, W. (2001). Inhaltsanalyse im World Wide Web. In W. Wirth, \& E. Lauf (Eds.), Inhaltsanalyse. Perspektiven, Probleme, Potentiale (pp. 280-302). Köln: Halem.

Saffer, A. J., Sommerfeldt, E. J., \& Taylor, M. (2013). The effects of organizational Twitter interactivity on organization-public relationships. Public Relations Review, 39(3), 213-215.

Saglie, J., \& Vabo, S. I. (2009). Size and e-democracy: Online participation in Norwegian local politics. Scandinavian Political Studies, 32(4), 382-401. doi:10.1111/j.1467-9477.2009.00235.x

Sanders, K., \& Canel, M. J. (Eds.). (2013). Government communication: Cases and challenges. New York: Bloomsbury Academic.

Saxer, U. (2009). Einführung und rechtsstaatliche Grundlagen. In B. Ehrenzeller, \& U. Saxer (Eds.): St. Galler Tagung zur Öffentlichkeitskommunikation des Staates. Recht und Praxis (pp. 1-26). St. Gallen: Institut für Rechtswissenschaft und Rechtspraxis.

Schweitzer, E. J. (2005). Election campaigning online. German party websites in the 2002 national elections. European Journal of Communication, 20(3), 327-351.

Schweitzer, E. (2010). Normalisierung 2.0. Die Online-Wahlkämpfe deutscher Parteien zu den Bundestagswahlen 2002-2009. In C. Holtz-Bacha (Ed.), Die Massenmedien im Wahlkampf. Das Wahljahr 2009 (pp. 189-244). Wiesbaden: VS.

Schweizerischer Städteverband (2012): Statistik der Schweizer Städte. Retrieved from https://www.stadtzuerich.ch/content/dam/stzh/prd/Deutsch/Statistik/Publikationsdatenbank/statistik_schweizer_staedte/STS T_2012-korr4.pdf, 18.08.2015.

Stromer-Galley, J. (2004). Interactivity-as-product and interactivity-as-process. The Information Society, 20(5), 391-394. doi:10.1080/01972240490508081

Sundar, S. S., Kalyanaraman, S., \& Brown, J. (2003). Explicating web site interactivity impression formation effects in political campaign sites. Communication Research, 30(1), 30-59. doi:10.1177/0093650202239025

Sustainable Governance Indicators. (2014). 2014 Switzerland Report. Gütersloh: Bertelsmann Stiftung. Retrieved from http://www.sginetwork.org/docs/2014/country/SGI2014_Switzerland.pdf, 18.08.2015.

Tambouris, E., Liotas, N., \& Tarabanis, K. (2007). A framework for assessing eParticipation projects and tools. Proceedings of the 40th Hawaii International Conference on System Sciences. Retrieved from http://ieeexplore.ieee.org/xpls/abs_all.jsp?arnumber=4076551\&tag=1 (10.01.2013).

Thackeray, R., Neiger, B. L., Smith, A. K., \& Van Wagenen, S. B. (2012). Adoption and use of social media among public health departments. BMC public health, 12(1), 1.

Van Dijck, J. (2013). 'You have one identity': Performing the self on Facebook and LinkedIn. Media, Culture \& Society, 35(2), 199-215. doi:10.1177/0163443712468605

Van Veenstra, A. F, Janssen, M., \& Boon, A. (2011). Measure to improve: A study of eParticipation in frontrunner Dutch municipalities. In E. Tambouris, A. Macintosh, \& H. de Bruijn (Eds.), Electronic participation: Third IFIP WG 8.5 international conference: Proceedings (pp. 157-168). Heidelberg: Springer.

Voorveld, H, Neijens, P., \& Smit, E. (2010). The interactive authority of brand web sites. A new tool provides new insights. Journal of Advertising Research, 50(3), 292-304. doi:10.2501/S0021849910091452

Voorveld, H., Neijens, P., \& Smit, E. (2011): The relation between actual and perceived interactivity. What makes the web sites of top global brands truly interactive? Journal of Advertising, 40(2), 77-92. doi:10.2753/JOA0091-3367400206

Wagschal, U. (1997). Direct democracy and public policymaking. Journal of Public Policy, 17(2), $223-245$.

doi:10.1017/S0143814X0000355X 
Table 1: Sample - Number of Swiss cities per language region and size

\begin{tabular}{|c|c|c|c|c|c|}
\hline City size (population) & German $\mathrm{CH}$ & French CH & Italian $\mathrm{CH}$ & Total CH & Total in \% \\
\hline$>100^{\prime} 000$ & 4 & 2 & 0 & 6 & $3.8 \%$ \\
\hline $50 ‘ 000-99 ‘ 999$ & 3 & 0 & 1 & 4 & $2.5 \%$ \\
\hline $20 ` 000-49 ‘ 999$ & 17 & 8 & 0 & 25 & $15.7 \%$ \\
\hline $15^{\prime} 000-19 ‘ 999$ & 29 & 10 & 2 & 41 & $25.8 \%$ \\
\hline $10^{\prime} 000-14^{\prime} 999$ & 50 & 14 & 1 & 65 & $40.9 \%$ \\
\hline$<10^{\prime} 000$ & 12 & 5 & 1 & 18 & $11.3 \%$ \\
\hline \multirow[t]{2}{*}{ Total cities } & 115 & 39 & 5 & 159 & $100.0 \%$ \\
\hline & $72.3 \%$ & $24.5 \%$ & $3.2 \%$ & $100 \%$ & \\
\hline \multirow[t]{2}{*}{ Total population in million } & 6.1 & 1.8 & 0.35 & 8.2 & \\
\hline & $73.6 \%$ & $22.1 \%$ & $4.3 \%$ & $100 \%$ & \\
\hline
\end{tabular}

Table 2: Interactive tools and language regions

\begin{tabular}{lccc}
\hline Region & Total Cities & Cities with Interactive tools & Number of interactive tools \\
\hline German CH & $115(100 \%)$ & $86(75 \%)$ & $336(82 \%)$ \\
French $\mathrm{CH}$ & $39(100 \%)$ & $26(72 \%)$ & $67(16,4 \%)$ \\
Italian $\mathrm{CH}$ & $5(100 \%)$ & $2(40 \%)$ & $6(1,5 \%)$ \\
Total & $159(100 \%)$ & $114(72 \%)$ & $409(100 \%)$ \\
\hline
\end{tabular}

Table 3: Types of interactive tools in percent $(\mathrm{N}=409)$

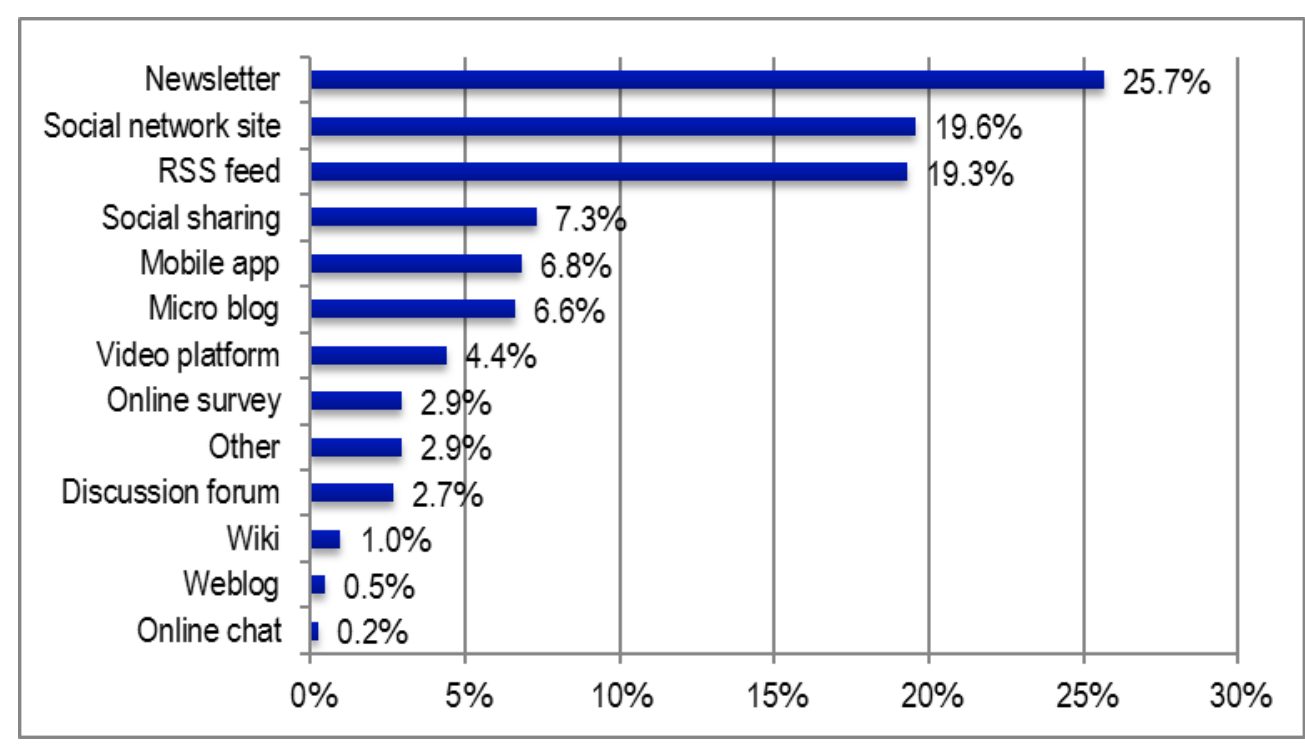


Table 4: Distribution of interactive tools and city size in percent and total $(\mathrm{N})$

\begin{tabular}{|c|c|c|c|c|c|c|c|}
\hline & & City size ( $p$ & ulation) & & & & \\
\hline & $\mathbf{n}$ & $<10^{\prime} 000$ & $\begin{array}{c}10^{\prime} 000- \\
14^{\prime} 999\end{array}$ & $\begin{array}{c}15^{\prime} 000- \\
19^{\prime} 999\end{array}$ & $\begin{array}{c}20 ‘ 000- \\
49^{\prime} 999\end{array}$ & $\begin{array}{c}50 ‘ 000- \\
99^{\prime} 999\end{array}$ & $>100^{\circ} 000$ \\
\hline Newsletter & 105 & $3.8(4)$ & $26.7(28)$ & $21.0(22)$ & $13.3(14)$ & $1.9(2)$ & $33.3(35)$ \\
\hline Social network site & 80 & $2.5(2)$ & $21.3(17)$ & $21.3(17)$ & $10(8)$ & $10.0(8)$ & $35(28)$ \\
\hline RSS feed & 79 & $3.8(3)$ & $30.4(24)$ & $19.0(15)$ & $19.0(15)$ & $3.8(3)$ & $24.1(19)$ \\
\hline Social sharing & 30 & $10.0(3)$ & $30.0(9)$ & $26.7(8)$ & $10(3)$ & $13.3(4)$ & $10(3)$ \\
\hline Mobile app & 28 & $3.6(1)$ & $25.0(7)$ & $32.1(9)$ & $14.3(4)$ & $7.1(2)$ & $17.9(5)$ \\
\hline Microblog & 27 & 0.0 & $7.4(2)$ & $11.1(3)$ & $18.5(5)$ & $11.1(3)$ & $51.9(14)$ \\
\hline Video platform & 18 & $5.6(1)$ & $22.2(4)$ & $33.3(6)$ & $5.6(1)$ & $5.6(1)$ & $27.8(5)$ \\
\hline Online survey & 12 & 0.0 & $58.3(7)$ & $8.3(1)$ & $8.3(1)$ & 0.0 & $25(3)$ \\
\hline Other & 12 & $8.3(1)$ & $16.7(2)$ & $8.3(1)$ & $25(3)$ & 0.0 & $41.7(5)$ \\
\hline Discussion forum & 11 & $9.1(1)$ & $27.3(3)$ & $18.2(2)$ & $18.2(2)$ & $18.2(2)$ & $9.1(1)$ \\
\hline Wiki & 4 & 0.0 & 0.0 & $50.0(2)$ & $50.0(2)$ & 0.0 & 0.0 \\
\hline Weblog & 2 & 0.0 & $50(1)$ & $50(1)$ & 0.0 & 0.0 & 0.0 \\
\hline Online Chat & 1 & 0.0 & $100(1)$ & 0.0 & 0.0 & 0.0 & 0.0 \\
\hline Total & 409 & $4.3(16)$ & $23.6(105)$ & $22.6(87)$ & $12.9(58)$ & $8.1(25)$ & $28.6(118)$ \\
\hline
\end{tabular}

(Reading examples: 51.9 percent ( $\mathrm{N}=14$ ) of all 27 microblogs were found in cities with a population over 100'000. 4.3 percent $(\mathrm{N}=16)$ of all 409 interactive tools were found in cities with a population under 10'000.) 


\section{Appendix}

Variables and inter-coder reliability

\begin{tabular}{|c|c|c|}
\hline Variable & Codes & $\begin{array}{l}\text { inter-coder reli- } \\
\text { ability (Holsti) }\end{array}$ \\
\hline $\begin{array}{l}\text { Type of interactive tool } \\
\text { (Schweitzer, 2005; Gibson \& Ward, } \\
\text { 2000; Tambouris et al., 2007; Macintosh, } \\
\text { 2008; Schweitzer, 2010; van Veenstra et } \\
\text { al., 2011) }\end{array}$ & \begin{tabular}{|l|} 
Newsletter \\
Social network site \\
RSS feed \\
Social sharing \\
Mobile app \\
Microblog \\
Video platform \\
Online survey \\
Other \\
Discussion forum \\
Wiki \\
Weblog \\
Online Chat
\end{tabular} & 0.800 \\
\hline $\begin{array}{l}\text { Interaction level } \\
\text { (Van Veenstra et al., 2011) }\end{array}$ & $\begin{array}{l}\text { Informing } \\
\text { Consulting } \\
\text { Advising } \\
\text { Co-Producing } \\
\text { Co-Decision }\end{array}$ & 0.768 \\
\hline $\begin{array}{l}\text { Interaction mode } \\
\text { (Schweitzer, 2010) }\end{array}$ & $\begin{array}{l}\text { One-to-one } \\
\text { one-to-many } \\
\text { many-to-many }\end{array}$ & 0.781 \\
\hline $\begin{array}{l}\text { Status in policy-cycle } \\
\text { (Tambouris et al., 2007) }\end{array}$ & $\begin{array}{l}\text { Problem articulation Problem definition } \\
\text { Policy definition } \\
\text { Development of programs } \\
\text { Policy implementation } \\
\text { Policy evaluation }\end{array}$ & 0.866 \\
\hline
\end{tabular}

